\title{
Streptococcus thermophilus: To Survive, or Not to Survive the Gastrointestinal Tract, That Is the Question!
}

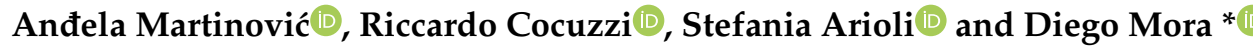 \\ Department of Food Environmental and Nutritional Sciences (DeFENS), University of Milan, via Celoria 2, \\ 20133 Milan, Italy; andjela.martinovic@unimi.it (A.M.); riccardo.cocuzzi@unimi.it (R.C.); \\ stefania.arioli@unimi.it (S.A.) \\ * Correspondence: diego.mora@unimi.it; Tel.: +39-0250319133
}

Received: 22 June 2020; Accepted: 20 July 2020; Published: 22 July 2020

\begin{abstract}
The probiotic market is increasing world-wide as well as the number of products marketed as probiotics. Among the latter, many products contain Streptococcus thermophilus strains at several dosages. However, the scientific evidence that should support the probiotic status of those S. thermophilus strains is often contradictory. This review analyses the scientific literature aimed to assess the ability of $S$. thermophilus strains to survive the human gastrointestinal tract by discussing the scientific validity of the methods applied for the bacterial recovery and identification from stool samples. This review highlights that in most of the intervention studies reviewed, the identification of $S$. thermophilus strains from stools was not carried out with the necessary taxonomic accuracy to avoid their misidentification with Streptococcus salivarius, a common human commensal and a species phylogenetically close to $S$. thermophilus. Moreover, this review highlights how critical the accurate taxonomic identification of $S$. thermophilus in metagenomics-based studies can be.
\end{abstract}

Keywords: S. salivarius; probiotics; taxonomy; recovery in fecal samples; microbiota

\section{Introduction}

According to the current definition of probiotics, "live microorganisms that, when administered in adequate amounts, confer a health benefit on the host" [1], the health-related probiotic traits (e.g., neurological, immunological, endocrinological effects) must be associated to a specific strain and depend on its viability (Live microorganisms) and dose administered (Adequate amounts). Nevertheless, there are also general, so-called Core benefits shared across a genus (e.g., regulation of intestinal transit, competitive exclusion of pathogens, normalization of perturbed microbiota) and species (e.g., direct antagonism, vitamin synthesis, enzymatic activity) level [1].

Most of the scientific literature dealing with the probiotic role of Streptococcus thermophilus strains starts from the assumption of the health benefit of yogurt consumption [2-5]. Yogurt is defined as a fermented milk based on the association of S. thermophilus and Lactobacillus delbrueckii subsp. bulgaricus. For this reason, strains belonging to these species have often been involved in scientific studies aimed to demonstrate their probiotic traits [6-10]. Due to its safe use in food production over the years, S. thermophilus was granted 'Generally Recognized as Safe' (GRAS) status in the USA and the 'Qualified Presumption of Safety' (QPS) status in the European Union [11]. Apart from being a constituent of yogurt, which has officially recognized probiotic properties (prerequisite is to contain at least $10^{8}$ colony-forming units (CFU)/g live microorganisms) [12], health benefits associated with S. thermophilus include production of antioxidant compounds, risk alleviation for some types of cancer, anti-inflammatory effects, antimutagenic effects and stimulation of the gut immune system [11-14]. 
The mitigating effect of yogurt consumption on lactose maldigestion has been officially recognized by European Food Safety Authority (EFSA) as a health claim [12]. In compliance with the Food and Agriculture Organization/World Health Organization (FAO/WHO) [15] modified definition of probiotics proposed by Hill and colleagues [1], such a beneficial effect has been attributed to the consumption of live bacterial cultures (S. thermophilus and L. delbrueckii subsp. bulgaricus) by several investigators [16-18]. For these reasons, probiotic products that include $S$. thermophilus strains are produced by multitudinous manufactures all over the world, such as those shown in Table 1. Most of the reported products (Table 1) are blends of several strains belonging to different species of lactic acid bacteria (e.g., Lactobacillus rhamnosus, L. acidophilus, L. bulgaricus, L. reuteri, Bifidobacterium bifidum, B. breve), Bacillus spp. (e.g., Bacillus coagulans, Bacillus subtilis, Bacillus clauslii) or the probiotic yeast Saccharomyces boulardii, with a CFU/dose ranging from 2 to 450 billion. Even though the market offers plenty of probiotic products containing $S$. thermophilus biomasses, the applicability of the term probiotic for this species itself is still questioned [19] due to its sensitivity to gastrointestinal tract (GIT) transit conditions.

Table 1. List of chosen probiotic products available on the international market containing S. thermophilus strains.

\begin{tabular}{|c|c|c|c|c|}
\hline Product Brand Name & $\begin{array}{l}\text { S. thermophiles } \\
\text { Strain }\end{array}$ & Manufacturer & $\begin{array}{l}\text { Colony-Forming Units } \\
\text { (CFU)/Dose }\end{array}$ & Country of Origin \\
\hline Fermental & n.d. & ESI S.r.l. & 2 bilions/capsule & Italy \\
\hline Floratrex & n.d. & Global Healing Center & 75 bilion $/ 0.8 \mathrm{~g}$ & USA \\
\hline Lactoflor $\mathrm{AB}$ & n.d. & Global Medic & 500 billion/capsule & Ecuador \\
\hline Lactoflor Probiotic & n.d. & Lactoflor & 2 billion $/ 0.4 \mathrm{~g}$ & Bulgaria \\
\hline Multibiotics & n.d. & NutriZing & 50 billions/g (capsules) & UK \\
\hline Neuflor & $\begin{array}{l}\text { Z57 (BCCM: LMG } \\
\text { P-21908) }\end{array}$ & Yamamoto nutrition & 56 billion $/ 0.8 \mathrm{~g}$ & Italy \\
\hline Nexabiotic Advanced & n.d. & DrFormulas & 17.25 billion/capsule & USA \\
\hline NOW Probiotic-10 & St-21 & NOW Foods & 50 billion/capsule & USA \\
\hline Oti Probioti & SP4 & $\begin{array}{l}\text { O.T.I. Officine Terapie } \\
\text { Innovative S.r.l. }\end{array}$ & 25.2 billion/ 4 capsules & Italy \\
\hline Perfect Biotics & n.d. & Probiotic America & 30 billion/capsule & USA \\
\hline Pro-100 Ultra & n.d. & Natures Aid & 100 billion/capsule & UK \\
\hline PRO-30 Max & n.d. & Natures Aid & 30 billion/capsule & UK \\
\hline PRO-B ACTIVE & n.d. & Lilly Drogerie & 14 bilions/capsule & Serbia \\
\hline PROBIO7 & n.d. & PROBIO & 4 billion/capsule & UK \\
\hline Probioguard & n.d. & Lamberts & 4 billion/capsule & UK \\
\hline Probiona Plus & n.d. & Tauron Ventures $\mathrm{GmbH}$ & 30 billion/capsule & Germany \\
\hline $\begin{array}{l}\text { Probiotic supplement } \\
\text { with vitamins }\end{array}$ & SD5207 & $\begin{array}{l}\text { L'Angelica Istituto } \\
\text { Erboristico }\end{array}$ & $\begin{array}{l}18 \text { billions/1.8 g (soluble } \\
\text { sticks) }\end{array}$ & Italy \\
\hline Prodefen & PXN 66 & Italfarmaco S. A & $\begin{array}{l}10 \text { billion L. rhamnosus }+1 \\
\text { bilion (other strains) } 1 \mathrm{~g} \\
\text { (sachets) }\end{array}$ & Spain \\
\hline Protexin Bio-Kult & PXN 66 & $\begin{array}{l}\text { Probiotics International } \\
\text { L.t.d. }\end{array}$ & 10 bilion/g (capsule) & UK \\
\hline Synbiotic365 & UASt-09 & United Naturals & 20 billion/capsule & Canada \\
\hline Ultra-potency & ST-21 & Custom Probiotics & 320 billion/ $0.8 \mathrm{~g}$ (powder) & USA \\
\hline Visbiome & DSM24731 & ExeGi Pharma & 1125 billion/g (capsule) & USA \\
\hline Vivomixx & DSM 24731 & Mendes S.A. & $\begin{array}{l}450 \text { billion/ } 4.4 \mathrm{~g} \text { (sachet) } \\
450 \text { billion/4.4 g (sachets) }\end{array}$ & Switzerland \\
\hline VSL\#3 & BT01 & Actial Farmaceutica S.r.l. & $\begin{array}{l}112 \text { billion/ } 658 \mathrm{mg} \\
\text { (capsules) } \\
45 \text { billion/ } 1.5 \mathrm{~g} \text { (sticks) }\end{array}$ & Italy \\
\hline Yovis & $\begin{array}{l}\text { Z57 (BCCM: LMG } \\
\text { P-219089) }\end{array}$ & AlfaSigma & $\begin{array}{l}50 \text { billion/1.5 g (sachets) } \\
50 \text { billion/ } 0.7 \mathrm{~g} \text { (capsules) } \\
25 \text { billion/10 } \mathrm{mL} \text { (falcons) }\end{array}$ & Italy \\
\hline
\end{tabular}

Abbreviations: n.d.: strain code not declared; DSM: German Collection of Microorganisms and Cell Cultures GmbH; BCCM: Belgian Co-ordinated Collections of Micro-organisms.

The capability of surviving the GIT is generally considered a key feature of probiotic strains $[1,20,21]$ and must be rigorously assessed. As highlighted by the FAO/WHO [15], typical in vitro tests such as resistance to gastric acidity and bile acid resistance require in vivo validation. One widespread way of doing so is the recovery of viable cells in fecal samples after oral administration, but are $S$. thermophilus strains easily recovered and correctly identified from stool samples? It is likely that 
other Streptococcus species, which inhabit the GIT, could be misidentified as S. thermophilus. Therefore, those taxonomic and ecological aspects should be considered in the intervention studies where S. thermophilus biomasses are administered, and in all the studies focused on the characterization of the human microbiota by metagenomics approaches. We review the scientific literature aimed to assess the ability of $S$. thermophilus strains to survive the human gastrointestinal tract by discussing the scientific validity of the methods applied for the bacterial recovery and identification from stool samples.

\section{Existing Knowledge on S. thermophilus Survival in the Gastrointestinal Tract (GIT) Transit Conditions}

Several studies attempted to assess the survival to the GIT of S. thermophilus by following different approaches, including culture-dependent and -independent methods or a combination of both [9,20,22-28] Mater et al. [20] quantified an orally administered streptomycin- and rifampicin-resistant $S$. thermophilus strain in fecal samples by standard plating, showing its substantial GIT survival in adults consuming yogurt. Similarly, Venturi et al. [22] described the recovery of S. thermophilus after oral administration of a multi-strain probiotic preparation by standard plating and also demonstrated the ability of S. thermophilus to survive the GIT. Subsequently, Brigidi et al. [23,24] and Mimura et al. [26] performed an identification and enumeration of S. thermophilus (combining both culture-dependent and -independent methods) from fecal samples after the administration of the same multi-strain probiotic product or yogurt, where they were able to recover significant numbers of S. thermophilus $[23,24,26]$ as well as to demonstrate its colonization pattern [24]. By contrast, a study by del Campo and colleagues [25] dealing with the recovery of $S$. thermophilus from fecal samples using plating and polymerase chain reaction (PCR) assay provided negative results for the GIT survival of $S$. thermophilus in humans during a crossover study after daily yogurt consumption for two weeks. Afterwards, Elli et al. [27] again confirmed that $S$. thermophilus can be retrieved from human feces after yogurt consumption. Later on, García Hernández and colleagues [9] revealed the GIT survival and colonization pattern of $S$. thermophilus in some subjects by applying a direct viable count-fluorescence in situ hybridization (DVC-FISH) method to fecal samples.

Since those studies gave contradictory results on the ability of $S$. thermophilus strains to survive GIT conditions, some authors are still arguing if it should be considered as a probiotic, thus naming S. thermophilus a Transient probiotic [11]. It must be noted that those differences in GIT survival rates observed in different studies could have also been generated by the genetic and phenotypic diversity of $S$. thermophilus strains and/or by differences in fermentation process parameters adopted for the production of the biomasses or by differences in the absolute number of live cells administered [29].

\section{Other Streptococci That Inhabit the Human GIT Could Interfere with the Correct Identification of S. thermophilus in Stool Samples}

When attempting to recover Streptococcus thermophilus from fecal samples, one often neglected but critical aspect is its phylogenetic similarity with two other closely related species, namely $S$. salivarius and S. vestibularis [30]. These three species, which are genetically very similar [30], belong to the S. salivarius subgroup of viridians streptococci. S. salivarius and S. vestibularis are commensal bacteria of the oral and gastrointestinal cavities and of the genital tract [31]. The genetic similarity between S. salivarius and S. thermophilus was so high that the latter was previously classified as a subspecies of S. salivarius (S. salivarius subsp. thermophilus), and it obtained the status of species on its own only in 1991 [32]. S. thermophilus was described as an example of regressive evolution for the adaptation to a food environment [33]. S. thermophilus has lost all pathogenic traits throughout its evolution and adaptation to a well-defined, narrow ecological niche, the milk [33,34]. The regressive evolution of S. thermophilus was supported by the finding of a vestige of pathogenesis-related genes $(10 \%$ of the total sequence), counterbalanced by the acquisition of relevant traits, like lactose and urea utilization, that have allowed the assembly of a new genome organization suitable for the colonization of the dairy niche $[33,34]$. The milk-driven speciation of $S$. thermophilus is also supported by the fact that this species 
is rarely, if ever, isolated outside the dairy environment [34]. However, the ability of S. thermophilus strains to utilize sucrose [34] with an efficiency comparable to that of lactose utilization led it to be hypothesized that this species could still be able to survive and grow in plant-based environments [35].

Sharing the same and being adapted to more natural and competitive niches, $S$. salivarius and S. vestibularis show a higher degree of physiological resemblance compared to $S$. thermophilus. For instance, S. salivarius and S. vestibularis have a higher capability to synthesize extracellular compounds (e.g., adhesins, exopolysaccharides) that are associated with bacterial fitness, resistance, biofilm formation and play a crucial role in cell adhesion, host colonization, or escape from the host immune system [30]. Moreover, the production of active urease, generally related to both health-associated and virulence factors is a common trait for all members of the $S$. salivarius group of streptococci [36]. The urease gene clusters of $S$. thermophilus and S. salivarius have similar organization (ureIABCDEFGMQO), with more complex transcriptional regulation in S. salivarius [37,38]. The well-known probiotic strain S. salivarius $\mathrm{K} 12$ is urease positive and can colonize the oral mucosae of humans regulating the innate immune responses of human epithelial cells [39]. In the case of the urease activity of $S$. thermophilus, Arioli and co-authors [40] observed that ammonia provided by urea hydrolysis boosted lactic acid production in both S. thermophilus and in L. delbrueckii, thus proposing urease activity as an altruistic cooperative trait. Regarding carbon sources utilization, $S$. salivarius can make use of a wider spectrum of compounds including glucose, fructose, galactose, lactose, as well as hydrolyze complex polymers such as starch or glucans [34]. On the other hand, S. thermophilus is well adapted to lactose as the main carbon source, hydrolyzing it to the glucose and galactose moieties. S. thermophilus is not able to metabolize galactose, expelling it outside the cell [34]. However, some galactose positive strains are reported [41]. Recently, multilocus sequence typing (MLST) and comparative genomic analysis gave novel insights into phylogeny, clearly separating these three species as well as indicating that $S$. thermophilus probably deviated from S. vestibularis $[30,42]$.

Concerning the safety aspect, there is an overall consensus on the safety status of $S$. thermophilus species, whereas few reports highlighted that $S$. salivarius and $S$. vestibularis strains may cause mild to severe human infections $[43,44]$.

Streptococcus spp. represent a notable part of the intestinal microbiota, with S. salivarius as one of the main species, indicating that these bacteria are actually able to colonize this ecological niche, rather than just being washed down with the flow of saliva [30,45-47]. S. salivarius has been recovered from fecal samples of infants, thus revealing that this species is one of the first inhabitants of the human gut $[48,49]$. Moreover, Delorme et al. [30] pointed out that previous metagenomic analysis of human feces revealed the presence of $S$. salivarius (formerly described as $S$. thermophilus due to a lack of appropriate genomic references) in more than $90 \%$ of the individuals tested $[30,50]$.

In the light of these considerations, the answer to the question "Could S. thermophilus be misidentified with other streptococci that inhabit the human GIT?" is: yes, if the genomic similarities between these species are not considered (Figure 1). 


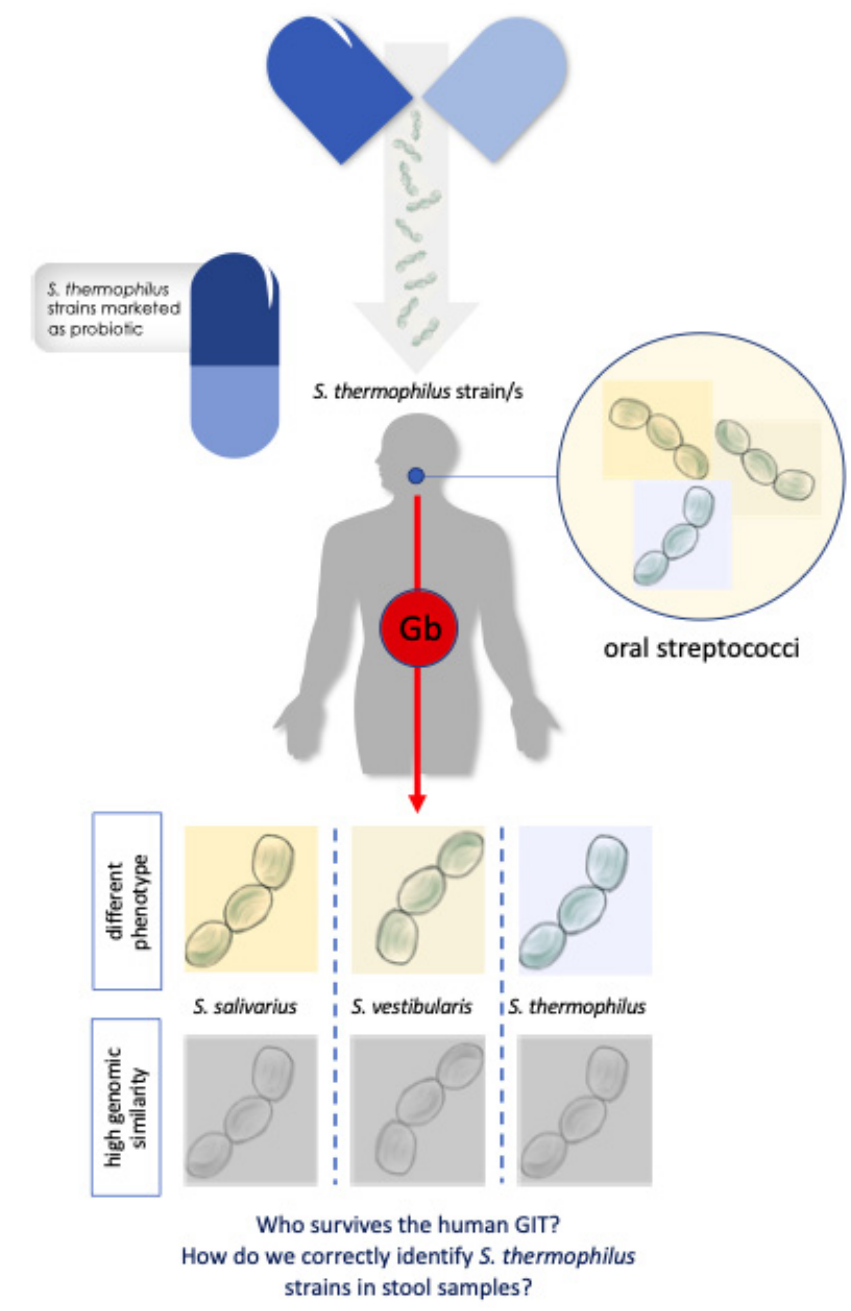

Figure 1. Schematic representation of the criticisms associated to the identification of $S$. thermophilus strains in human stool samples during intervention studies. Gb, gastric barrier; GIT, gastrointestinal tract.

\section{The Methods Applied in the Reviewed Literature to Identify S. thermophilus Strains Were Not Selective at Species Level}

We previously showed that some studies, dealing with the survival of $S$. thermophilus to the human GIT, based their assumptions on the recovery of $S$. thermophilus from the stool of human subjects after the consumption of yogurt or probiotic preparations [9,20,23-28]. Most of the studies indicated substantial $[9,20,23,24,26-28]$ or no survival [25] of S. thermophilus strains after consumption of yogurt or probiotic products containing this species. What are the reasons for these contradictory conclusions? In most of the studies, the authors have paid little attention to the culture-dependent methods applied to recover live $S$. thermophilus strains from stool samples. The culture-dependent plating technique on specific selective media (e.g., ST agar, ST agar supplemented with the $\mathrm{pH}$ indicators bromocresole purple and bromocresole green, and the antibiotic nalidixic acid) used in some studies [22-24,28] was shown [23] to be ineffective for the selective identification and enumeration of $S$. thermophilus after the administration of a dairy or probiotic product, due to the inability to discriminate $S$. thermophilus from intestinal streptococci and enterococci as well as the phylogenetically closely related S. salivarius [23]. Therefore, the possibility to misidentify $S$. thermophilus with $S$. salivarius, the closest neighbor inhabiting the oral cavity, was likely underestimated. In addition, competitive inhibition by autochthonous bacteria from the gut, which may hinder the growth of $S$. thermophilus in the plate, cannot be excluded. Mater and colleagues [20] tried to selectively isolate S. thermophilus S85, which was streptomycin and 
rifampicin resistant, by adding the two antibiotics to the medium used for the recovery from fecal samples; however, the sensitivity of $S$. salivarius strains to streptomycin and rifampicin was not verified, nor was a molecular identification performed on the isolated colonies to confirm their taxonomy. Therefore, to date, the data about the accurate identification and retrieval of $S$. thermophilus in human subjects upon administration of yogurt or probiotic preparations are debatable.

\subsection{Are the Data Supporting the GIT Survival of S. thermophilus Strains Solid and Unbiased Enough to Generate Scientific Consensus?}

A list of molecular tools developed for the identification of $S$. thermophilus, together with the limitations detected for each of them, is shown in Table 2. Some of the tools listed in Table 2 have been developed aiming to identify $S$. thermophilus from fermented dairy products. These tools are based on species-specific polymerase chain reaction (PCR) primers targeting the $16 S \mathrm{rDNA}$ gene sequence [51,52]. However, the $16 S$ rDNA gene sequence is not specific enough because of a high identity among those sequences in S. thermophilus, S. salivarius and S. vestibuilaris species $(99.8 \%$ between $S$. thermophilus and S. salivarius; 99.6\% between S. thermophilus and S. vestibularis) [53]. Lick and Teuber [54] designed species-specific oligonucleotide probes based on the $5^{\prime}$ region of the lacZ gene, but they showed both specific and non-specific hybridization signals among different strains of $S$. thermophilus and $S$. salivarius. Later on, species-specific PCR primers targeting the lac Z gene were developed [55]. This primer set was validated using several $S$. thermophilus strains and two $S$. salivarius strains as a reference [55]. However, subsequent studies demonstrated the inability of lac $Z$ gene primers to correctly identify S. thermophilus strains [27].

Table 2. Overview of tools used in interventional studies for viability assessment of S. thermophilus.

\begin{tabular}{|c|c|c|c|c|c|}
\hline Product & Used Tool & $\begin{array}{c}\text { Target } \\
\text { Species/Gene }\end{array}$ & Species-Specificity & $\begin{array}{l}\text { Other Potentially } \\
\text { Detected Species }\end{array}$ & Reference \\
\hline $\begin{array}{l}\text { Probiotic food } \\
\text { supplement }\end{array}$ & Standard plating & S. thermophilus & no & $\begin{array}{l}\text { S. salivarius, } S \text {. } \\
\text { vestibularis }\end{array}$ & [22] \\
\hline $\begin{array}{l}\text { Probiotic food } \\
\text { supplement }\end{array}$ & End-point PCR & $\begin{array}{l}16 S-23 S \text { rDNA } \\
\text { spacer region }\end{array}$ & no & $\begin{array}{l}\text { S. salivarius, } S . \\
\text { vestibularis }\end{array}$ & [23] \\
\hline $\begin{array}{c}\text { Probiotic food } \\
\text { supplement and } \\
\text { Yogurt }\end{array}$ & $\begin{array}{l}\text { End-point PCR, } \\
\text { qPCR }\end{array}$ & $\begin{array}{l}16 S-23 S r D N A \\
\text { spacer region }\end{array}$ & no & $\begin{array}{l}\text { S. salivarius, } S \text {. } \\
\text { vestibularis }\end{array}$ & [24] \\
\hline $\begin{array}{l}\text { Probiotic food } \\
\text { supplement }\end{array}$ & End-point PCR & $\begin{array}{l}16 S-23 S r D N A \\
\text { spacer region }\end{array}$ & no & $\begin{array}{l}\text { S. salivarius, } S \text {. } \\
\text { vestibularis }\end{array}$ & [26] \\
\hline Yogurt & $\begin{array}{c}\text { End-point PCR, } \\
\text { DNA-hybridization }\end{array}$ & lacZ gene & no & $\begin{array}{l}\text { S. salivarius, } S \text {. } \\
\text { vestibularis }\end{array}$ & [25] \\
\hline Yogurt & $\begin{array}{c}\text { End-point PCR, } \\
\text { PFGE }\end{array}$ & $\begin{array}{c}\text { lacZ gene, Profiles } \\
\text { of SmaI-digested } \\
\text { chromosomes }\end{array}$ & no & $\begin{array}{l}\text { S. salivarius, } S \text {. } \\
\text { vestibularis }\end{array}$ & [27] \\
\hline Yogurt & DVC-FISH & $23 S$ rRNA & no & $\begin{array}{l}\text { S. salivarius, } S . \\
\text { vestibularis }\end{array}$ & [9] \\
\hline
\end{tabular}

Abbreviations: PCR: polymerase chain reaction; qPCR: quantitative polymerase chain reaction; PFGE: pulsed-field gel electrophoresis.

In 1997, Tilsala-Timisjärvi and Alatossava [56] designed the ThI/ThII PCR species-specific primer set, based on the internal transcribed spacer between the $16 S$ and the $23 S$ rDNA genes for the detection of $S$. thermophilus in dairy products. In this study, the authors underlined that this primer set was most probably not able to distinguish between $S$. thermophilus and S. salivarius, which, being a closely related species, has an almost identical spacer sequence between the $16 S$ rDNA and the $23 S$ rDNA genes. Subsequently, Mora and colleagues [41], analyzing the sequence of the 16S-23S rDNA spacer region, demonstrated that a simple end-point PCR assay carried out using ThI/ThII primers was ineffective to discriminate between S. salivarius, S. thermophilus, S. bovis, S. macedonicus, S. waius and S. infantarius species. Nevertheless, the two primers were used in various intervention studies to carry out the identification of $S$. thermophilus strains recovered from stool samples $[23,24,26]$. More specifically, Brigidi et al. [23] performed an identification and enumeration of $S$. thermophilus from fecal samples of 
individuals who had been taking a multi-strain probiotic product using ThI/ThII primers, reporting a significant increase of $S$. thermophilus after administration of this probiotic product. Later, the same group of authors conducted a similar study using a culture-independent quantitative polymerase chain reaction (qPCR) method with the same primer set (ThI/ThII) for the identification and enumeration of several $S$. thermophilus strains showing its survival as well as colonization pattern after administration of both a probiotic preparation and commercial yogurt [24]. However, quantitative PCR of S. thermophilus was applied directly on feces, thus it was not possible to discriminate between live and dead cells as well as free DNA originated from lysed cells. In this case, a propidium monoazide (PMA-qPCR)-based methodology [57] would have been appropriate to directly quantify live $S$. thermophilus cells excluding dead cells and free DNA from the fecal samples. Moreover, in this study the primers where accurately tested for specificity against some intestinal and dairy species, among them $S$. faecium (several strains), Lactobacillus acidophilus (several strains), L. brevis, L. casei, L. crispatus, L. delbrueckii subsp. delbrueckii (several strains), L. delbrueckii subsp. lactis, Lactococcus lactis, (several strains), L. lactis subsp. cremoris (several strains), L. lactis subsp. lactis biovar diacetylactis, Escherichia coli (several strains), Enterococcus fecalis (several strains), Clostridium beijerinkii, C. perfringens, Bacteroides fragilis (several strains), Bifidobacterium bifidum (several strains), B. infantis (several strains), B. longum (several strains), B. adolescentis (several strains) but not against the phylogenetically close S. salivarius. Similarly, Mimura et al. [26] demonstrated higher levels of $S$. thermophilus after administration of a multi-strain probiotic product using the same primer set. These studies, based on the use of ThI/ThII primers, also showed that some of the subjects harbored S. thermophilus even after the run in and prior to treatment period, where the subjects were asked not to consume any food products containing this species. Therefore, we can speculate that primers may have actually detected S. salivarius strains, providing misleading results.

Contrary to previous data, del Campo and colleagues [25] provided scarce evidence of S. thermophilus recovery in human feces after daily yogurt consumption. In this study, not a single positive amplification for $S$. thermophilus was obtained from the total fecal DNA of 114 volunteers. The authors attempted to detect $S$. thermophilus using the THER-F/THER-R primer set, which is targeted to the lacZ gene. Nevertheless, due to some weaknesses in the protocols adopted for DNA extraction from fecal samples, the results obtained may have not been correctly analyzed. In addition, the specificity of the THER-F/THER-R primers for $S$. thermophilus was questioned in a later study by Elli and colleagues [27] who demonstrated that this primer set was not specific enough to set apart S. salivarius and detect exclusively S. thermophilus. Due to the lack of efficient identification methods, the same authors carried out a pulsed-field gel electrophoresis (PFGE) based on different SmaI digested chromosomes, in order to distinguish these two genetically close species and recover $S$. thermophilus from the feces of 20 healthy volunteers who had been consuming commercial yogurt. Likewise, it was suggested that there is a need for reliable molecular tools for the identification of orally administered $S$. thermophilus strains. In a 2012 study, García Hernández and colleagues [9] for the first time applied the DVC-FISH method to fecal samples for the elucidation of the survival rate of $S$. thermophilus strain CECT 801 to GIT transit. It must be observed, however, that the FISH probe used in the study, namely STH23 targeting the 23S rRNA gene, may not be specific enough for S. thermophilus because only one single base mismatch was present between the FISH probe target region of $S$. thermophilus and $S$. salivarius. In 2009, Ongol et al. [58] developed a real-time PCR method targeting a gene encoding a $16 \mathrm{~S}$ rRNA processing protein (rimM) for the detection of $S$. thermophilus in dairy products. The authors tested the primer set against several lactic acid bacteria, including S. salivarius, demonstrating its high specificity but failed to amplify some $S$. thermophilus strains.

In light of the scientific literature cited we can, therefore, conclude that to date there are no taxonomically correct assays that allow to unambiguously identify $S$. thermophilus strains and distinguish them from those belonging to $S$. salivarius in a stool sample. 


\subsection{Culture-Independent Detection and Identification of S. thermophilus}

The problems related to the incorrect identification of $S$. thermophilus are not limited to the studies aimed to verify the recovery of live cells in stool samples during intervention studies. We are living in the microbiota era, and the role of microorganisms is becoming increasingly relevant in all ecosystems, including the human ecosystem. Several studies have been focused on the role of diet- and food-associated microorganisms on gut microbiota and human health. The complexity of the taxonomy of $S$. thermophilus/S. salivarius/S. vestibularis group was often completely ignored also in this research field. Francavilla and colleagues [59], in a study aimed to characterize the salivary microbiota and metabolome associated with celiac disease, reported that $S$. thermophilus levels in human saliva were markedly decreased in a group of subjects that undergo a gluten-free diet. In this study saliva microbiota was characterized by $16 S \mathrm{r} R N A$ gene amplicon library sequencing, and the authors did not take into consideration both the taxonomy and the ecology of the environment they studied, making the readers erroneously believe that $S$. thermophilus is a common inhabitant of our oral cavity. More recently, Pasolli and colleagues [60] published an interesting study aimed to elucidate to what extent the lactic acid bacteria we ingest through the consumption of fermented food become members of the gut microbiome. The authors analyzed 9445 metagenomes from human samples and demonstrated that the prevalence and abundance of lactic acid bacteria species in stool samples is generally low and linked to age, lifestyle, and geography, with $S$. thermophilus being one of the most prevalent species [60]. To reach this conclusion, the authors focused on a defined list of genomes to be used as reference for the quantification of the prevalence of lactic acid bacteria species in the human gut, but unfortunately only the genome of $S$. thermophilus was present in the list, whereas the genome of S. salivarius was not considered at all [60] although the latter is recognized as a major human commensal [30]. Therefore, how can we provide adequate scientific evidence towards the statement that the increased consumption of yogurts and other dairy products are the sources of S. thermophilus in our gut ecosystem? Moreover, which metabolic features of S. thermophilus would guarantee adaptation of this species to the human gut environment? Why did the authors not consider that $S$. thermophilus was described as an example of genomic regressive evolution for adaptation to the milk environment $[33,34]$ ? In other studies $[61,62]$ aimed to find correlation between the diet and the gut microbiota composition, where the proper reference genomes have been used, $S$. thermophilus was not considered as a human gut inhabitant.

\section{Conclusions}

Growing interest in the probiotic market, together with the increasing number of single and multi-strain products, is not always accompanied by scientific studies aimed to address the health benefit on the host of such products. In the last few years, some efforts have been made to evaluate the quality levels of products that are commercialized [63-67]. However, limited efforts have been made to develop molecular or phenotypic tools able to accurately identify the species and/or the strains administered as probiotics in intervention studies. The accurate taxonomic identification is, therefore, a paramount issue to be validated for the compliance of probiotic food and supplement products. Without a correct taxonomy assignment of the species/strains that should contain probiotic traits, the interpretation of the results obtained from the intervention studies is thwarted. This is especially the case of S. thermophilus, whose probiotic status has been in debate for decades. Being $S$. thermophilus a species with high economic relevance for the probiotic market, and $S$. salivarius one of the major human commensals able to colonize several human body-related sites, including the digestive tract [30], the correct identification of these taxa should be of high interest for the food and pharma industry. Another important issue arising from the reviewed literature is the absence of guidelines and protocols for the recovery from stool samples of orally ingested probiotics. The guidelines should recommend a proper study design based on a double-blind, placebo-controlled crossover design, an appropriate washout period together with the application of a species-specific plate culture method (if available), and/or the use of strain-specific molecular tools to correctly identify the orally administered probiotic/s. Moreover, 
among the commonly adopted exclusion criteria used in the intervention studies (e.g., antibiotic consumption prior to the start of the study, consumption of antacids or prokinetic gastrointestinal drugs, history or presence of significant intestinal diseases) the exclusion of the subjects showing a positive detection of probiotic strain in fecal samples during the run in or the placebo intake period should be considered because it might represent a possible compliance violation due to unauthorized probiotic intake.

Author Contributions: Conceptualization, D.M.; methodology, D.M. and S.A.; investigation, A.M. and R.C.; writing - original draft preparation, A.M. and R.C.; writing-review and editing, D.M., A.M., R.C. and S.A.; supervision, D.M. All authors have read and agreed to the published version of the manuscript.

Funding: University of Milan partially covered the open access APC.

Conflicts of Interest: The authors declare no conflict of interest.

\section{References}

1. Hill, C.; Guarner, F.; Reid, G.; Gibson, G.R.; Merenstein, D.J.; Pot, B.; Morelli, L.; Canani, R.B.; Flint, H.J.; Salminen, S.; et al. The International Scientific Association for Probiotics and Prebiotics Consensus Statement on the Scope and Appropriate Use of the Term Probiotic. Nat. Rev. Gastroenterol. Hepatol. 2014, 11, 506-514. [CrossRef] [PubMed]

2. Halpern, G.M.; Vruwink, K.G.; Van De Water, J.; Keen, C.L.; Gershwin, M.E. Influence of Long-Term Yoghurt Consumption in Young Adults. Int. J. Immunol. Immunother. 1991, 7, 205-210.

3. Martini, M.C.; Lerebours, E.C.; Lin, W.J.; Harlander, S.K.; Berrada, N.M.; Antoine, J.M.; Savaiano, D.A. Strains and Species of Lactic Acid Bacteria in Fermented Milks (Yogurts): Effect on in vivo Lactose Digestion. Am. J. Clin. Nutr. 1991, 54, 1041-1046. [CrossRef] [PubMed]

4. Rizkalla, S.W.; Luo, J.; Kabir, M.; Chevalier, A.; Pacher, N.; Slama, G. Chronic Consumption of Fresh but Not Heated Yogurt Improves Breath-Hydrogen Status and Short-Chain Fatty Acid Profiles: A Controlled Study in Healthy Men with or without Lactose Maldigestion. Am. J. Clin. Nutr. 2000, 72, 1474-1479. [CrossRef]

5. Zhu, Y.; Wang, H.; Hollis, J.H.; Jacques, P.F. The Associations between Yogurt Consumption, Diet Quality, and Metabolic Profiles in Children in the USA. Eur. J. Nutr. 2015, 54, 543-550. [CrossRef]

6. Boke, H.; Aslim, B.; Alp, G. The Role of Resistance to Bile Salts and Acid Tolerance of Exopolysaccharides (EPSS) Produced by Yogurt Starter Bacteria. Arch. Biol. Sci. 2010, 62, 323-328. [CrossRef]

7. Fang, S.-H.; Lai, Y.-J.; Chou, C.-C. The Susceptibility of Streptococcus thermophilus 14085 to Organic Acid, Simulated Gastric Juice, Bile Salt and Disinfectant as Influenced by Cold Shock Treatment. Food Microbiol. 2013, 33, 55-60. [CrossRef]

8. Vinderola, C.G.; Reinheimer, J.A. Lactic Acid Starter and Probiotic Bacteria: A Comparative "in vitro" Study of Probiotic Characteristics and Biological Barrier Resistance. Food Res. Int. 2003, 36, 895-904. [CrossRef]

9. García-Hernández, J.; Moreno, Y.; Chuan, C.; Hernández, M. In vivo Study of the Survival of Lactobacillus delbruecki subsp. bulgaricus CECT 4005 T and Streptococcus thermophilus CECT 801 by DVC-FISH after Consumption of Fermented Milk. J. Food Sci. 2012, 77, M593-M597. [CrossRef]

10. Junjua, M.; Kechaou, N.; Chain, F.; Awussi, A.A.; Roussel, Y.; Perrin, C.; Roux, E.; Langella, P.; Bermúdez-Humarán, L.G.; Le Roux, Y.; et al. A Large Scale in vitro Screening of Streptococcus thermophilus Strains Revealed Strains with a High Anti-Inflammatory Potential. LWT 2016, 70, 78-87. [CrossRef]

11. Iyer, R.; Tomar, S.K.; Uma Maheswari, T.; Singh, R. Streptococcus thermophilus Strains: Multifunctional Lactic Acid Bacteria. Int. Dairy J. 2010, 20, 133-141. [CrossRef]

12. EFSA. Scientific Opinion on the Substantiation of Health Claims Related to Live Yoghurt Cultures and Improved Lactose Digestion (ID 1143, 2976) Pursuant to Article 13(1) of Regulation (EC) No 1924/2006. EFSA J. 2010, 18, 763.

13. Iyer, R.; Tomar, S.K.; Kapila, S.; Mani, J.; Singh, R. Probiotic Properties of Folate Producing Streptococcus thermophilus Strains. Food Res. Int. 2010, 43, 103-110. [CrossRef]

14. Mizuno, H.; Tomotsune, K.; Islam, M.A.; Funabashi, R.; Albarracin, L.; Ikeda-Ohtsubo, W.; Aso, H.; Takahashi, H.; Kimura, K.; Villena, J.; et al. Exopolysaccharides From Streptococcus thermophilus ST538 Modulate the Antiviral Innate Immune Response in Porcine Intestinal Epitheliocytes. Front. Microbiol. 2020, 11, 894. [CrossRef] [PubMed] 
15. FAO/WHO. Guidelines for the Evaluation of Probiotics in Food. May 2002. Available online: https: //www.who.int/foodsafety/fs_management/en/probiotic_guidelines.pdf (accessed on 21 July 2020).

16. Dewit, O.; Pochart, P.; Desjeux, J.-F. Breath Hydrogen Concentration and Plasma Glucose, Insulin and Free Fatty Acid Levels after Lactose, Milk, Fresh or Heated Yogurt Ingestion by Healthy Young Adults with or without Lactose Malabsorption. Nutrition 1988, 4, 131-135.

17. Labayen, I.; Forga, L.; Gonzalez, A.; Lenoir-Wijnkoop, I.; Nutr, R.; Martinez, J.A. Relationship between Lactose Digestion, Gastrointestinal Transit Time and Symptoms in Lactose Malabsorbers after Dairy Consumption. Aliment. Pharmacol. Ther. 2001, 15, 543-549. [CrossRef]

18. Pelletier, X.; Laure-Boussuge, S.; Donazzolo, Y. Original Communication Hydrogen Excretion upon Ingestion of Dairy Products in Lactose- Intolerant Male Subjects: Importance of the Live Flora. Eur. J. Clin. Nutr. 2001, 55, 509-512. [CrossRef]

19. Uriot, O.; Denis, S.; Junjua, M.; Roussel, Y.; Dary-Mourot, A.; Blanquet-Diot, S. Streptococcus thermophilus: From Yogurt Starter to a New Promising Probiotic Candidate? J. Funct. Foods 2017, 37, 74-89. [CrossRef]

20. Mater, D.D.G.; Bretigny, L.; Firmesse, O.; Flores, M.-J.; Mogenet, A.; Bresson, J.-L.; Corthier, G. Streptococcus thermophilus and Lactobacillus delbrueckii subsp. bulgaricus Survive Gastrointestinal Transit of Healthy Volunteers Consuming Yogurt. FEMS Microbiol. Lett. 2005, 250, 185-187. [CrossRef]

21. De Melo Pereira, G.V.; de Oliveira Coelho, B.; Magalhães Júnior, A.I.; Thomaz-Soccol, V.; Soccol, C.R. How to Select a Probiotic? A Review and Update of Methods and Criteria. Biotechnol. Adv. 2018, 36, $2060-2076$. [CrossRef]

22. Venturi, A.; Gionchetti, P.; Rizzello, F.; Johansson, R.; Zucconi, E.; Brigidi, P.; Matteuzzi, D.; Campieri, M. Impact on the Composition of the Faecal Flora by a New Probiotic Preparation: Preliminary Data on Maintenance Treatment of Patients with Ulcerative Colitis. Aliment. Pharm. Ther. 1999, 13, 1103-1108. [CrossRef] [PubMed]

23. Brigidi, P.; Vitali, B.; Swennen, E.; Bazzocchi, G.; Matteuzzi, D. Effects of Probiotic Administration upon the Composition and Enzymatic Activity of Human Fecal Microbiota in Patients with Irritable Bowel Syndrome or Functional Diarrhea. Res. Microbiol. 2001, 152, 735-741. [CrossRef]

24. Brigidi, P.; Swennen, E.; Vitali, B.; Rossi, M.; Matteuzzi, D. PCR Detection of Bifidobacterium Strains and Streptococcus thermophilus in Feces of Human Subjects after Oral Bacteriotherapy and Yogurt Consumption. Int. J. Food Microbiol. 2003, 81, 203-209. [CrossRef]

25. Bravo, D.; Cantón, R.; Ruiz-Garbajosa, P.; García-Albiach, R.; Montesi-Libois, A.; Yuste, F.-J.; Abraira, V.; Baquero, F. Scarce Evidence of Yogurt Lactic Acid Bacteria in Human Feces after Daily Yogurt Consumption by Healthy Volunteers. Appl. Environ. Microbiol. 2005, 71, 547-549. [CrossRef]

26. Mimura, T.; Rizzello, F.; Helwig, U.; Poggioli, G.; Schreiber, S.; Talbot, I.C.; Nicholls, R.J.; Gionchetti, P.; Campieri, M.; Kamm, M.A. Once Daily High Dose Probiotic Therapy (VSL\#3) for Maintaining Remission in Recurrent or Refractory Pouchitis. Gut 2004, 53, 108-114. [CrossRef] [PubMed]

27. Elli, M.; Callegari, M.L.; Ferrari, S.; Bessi, E.; Cattivelli, D.; Soldi, S.; Morelli, L.; Goupil Feuillerat, N.; Antoine, J.-M. Survival of Yogurt Bacteria in the Human Gut. Appl. Environ. Microbiol. 2006, 72, 5113-5117. [CrossRef]

28. Rajkumar, H.; Mahmood, N.; Kumar, M.; Varikuti, S.R.; Challa, H.R.; Myakala, S.P. Effect of Probiotic (VSL\#3) and Omega-3 on Lipid Profile, Insulin Sensitivity, Inflammatory Markers, and Gut Colonization in Overweight Adults: A Randomized, Controlled Trial. Mediat. Inflamm. 2014, 2014, 1-8. [CrossRef]

29. Fenster, K.; Freeburg, B.; Hollard, C.; Wong, C.; Rønhave Laursen, R.; Ouwehand, A. The Production and Delivery of Probiotics: A Review of a Practical Approach. Microorganisms 2019, 7, 83. [CrossRef]

30. Delorme, C.; Abraham, A.-L.; Renault, P.; Guédon, E. Genomics of Streptococcus salivarius, a Major Human Commensal. Infect. Genet. Evol. 2015, 33, 381-392. [CrossRef]

31. Kawamura, Y.; Hou, X.-G.; Sultana, F.; Miura, H.; Ezaki, T. Determination of 16S RRNA Sequences of Streptococcus mitis and Streptococcus gordonii and Phylogenetic Relationships among Members of the Genus Streptococcus. Int. J. Syst. Bacteriol. 1995, 45, 406-408. [CrossRef]

32. Schleifer, K.H.; Ehrmann, M.; Krusch, U.; Neve, H. Revival of the Species Streptococcus thermophilus (Ex Orla-Jensen, 1919) nom. rev. Syst. Appl. Microbiol. 1991, 14, 386-388. [CrossRef]

33. Bolotin, A.; Quinquis, B.; Renault, P.; Sorokin, A.; Ehrlich, S.D.; Kulakauskas, S.; Lapidus, A.; Goltsman, E.; Mazur, M.; Pusch, G.D.; et al. Complete Sequence and Comparative Genome Analysis of the Dairy Bacterium Streptococcus thermophilus. Nat. Biotechnol. 2004, 22, 1554-1558. [CrossRef] [PubMed] 
34. Hols, P.; Hancy, F.; Fontaine, L.; Grossiord, B.; Prozzi, D.; Leblond-Bourget, N.; Decaris, B.; Bolotin, A.; Delorme, C.; Dusko Ehrlich, S.; et al. New Insights in the Molecular Biology and Physiology of Streptococcus thermophilus Revealed by Comparative Genomics. FEMS Microbiol. Rev. 2005, 29, 435-463. [CrossRef] [PubMed]

35. Arioli, S.; Eraclio, G.; Della Scala, G.; Neri, E.; Colombo, S.; Scaloni, A.; Fortina, M.G.; Mora, D. Role of Temperate Bacteriophage $\Phi 20617$ on Streptococcus thermophilus DSM 20617T Autolysis and Biology. Front. Microbiol. 2018, 9, 2719. [CrossRef] [PubMed]

36. Mora, D.; Arioli, S. Microbial Urease in Health and Disease. PLoS Pathog. 2014, 10, e1004472. [CrossRef]

37. Mora, D.; Maguin, E.; Masiero, M.; Parini, C.; Ricci, G.; Manachini, P.L.; Daffonchio, D. Characterization of Urease Genes Cluster of Streptococcus thermophilus. J. Appl. Microbiol. 2004, 96, 209-219. [CrossRef] [PubMed]

38. Chen, Y.-Y.M.; Burne, R.A. Identification and Characterization of the Nickel Uptake System for Urease Biogenesis in Streptococcus salivarius 57.I. J. Bacteriol. 2003, 185, 6773-6779. [CrossRef]

39. Power, D.A.; Burton, J.P.; Chilcott, C.N.; Dawes, P.J.; Tagg, J.R. Preliminary Investigations of the Colonisation of Upper Respiratory Tract Tissues of Infants Using a Paediatric Formulation of the Oral Probiotic Streptococcus salivarius K12. Eur. J. Clin. Microbiol. Infect. Dis. 2008, 27, 1261-1263. [CrossRef]

40. Arioli, S.; Della Scala, G.; Remagni, M.C.; Stuknyte, M.; Colombo, S.; Guglielmetti, S.; De Noni, I.; Ragg, E.; Mora, D. Streptococcus thermophilus Urease Activity Boosts Lactobacillus delbrueckii subsp. bulgaricus Homolactic Fermentation. Int. J. Food Microbiol. 2017, 247, 55-64. [CrossRef]

41. Mora, D.; Fortina, M.G.; Parini, C.; Ricci, G.; Gatti, M.; Giraffa, G.; Manachini, P.L. Genetic Diversity and Technological Properties of Streptococcus thermophilus Strains Isolated from Dairy Products. J. Appl. Microbiol. 2002, 93, 278-287. [CrossRef]

42. Yu, J.; Sun, Z.; Liu, W.; Xi, X.; Song, Y.; Xu, H.; Lv, Q.; Bao, Q.; Menghe, B.; Sun, T. Multilocus Sequence Typing of Streptococcus thermophilus from Naturally Fermented Dairy Foods in China and Mongolia. BMC Microbiol. 2015, 15, 236. [CrossRef] [PubMed]

43. Idigoras, P.; Valiente, A.; Iglesias, L.; Trieu-Cuot, P.; Poyart, C. Meningitis Due to Streptococcus salivarius. J. Clin. Microbiol. 2001, 39, 3017. [CrossRef] [PubMed]

44. Doyuk, E.; Ormerod, O.J.; Bowler, I.C.J.W. Native Valve Endocarditis Due to Streptococcus vestibularis and Streptococcus oralis. J. Infect. 2002, 45, 39-41. [CrossRef] [PubMed]

45. Almeida, M.; Achouri, E.; Moumen, B.; Le Chatlier, E.; Pons, N.; Batto, P.; Léonard, P.; Kennedy, S.; Boumezbeur, F.; Layec, S.; et al. Streptococci in the Human Digestive Tract A Metagenomic Study. In 18th Lancefield International Symposium on Streptococci and Streptococcal Disease; Rockefeller University: New York, NY, USA, 2011.

46. van Den Bogert, B.; Erkus, O.; Boekhorst, J.; de Goffau, M.; Smid, E.J.; Zoetendal, E.G.; Kleerebezem, M. Diversity of Human Small Intestinal Streptococcus and Veillonella Populations. FEMS Microbiol. Ecol. 2013, 85, 376-388. [CrossRef] [PubMed]

47. Watanabe, T.; Shimohashi, H.; Kawai, Y.; Mutai, M. Studies on Streptococci: I. Distribution of Fecal Streptococci in Man. Microbiol. Immunol. 1981, 25, 257-269. [CrossRef] [PubMed]

48. Favier, C.F.; Vaughan, E.E.; De Vos, W.M.; Akkermans, A.D.L. Molecular Monitoring of Succession of Bacterial Communities in Human Neonates. Appl. Environ. Microbiol. 2002, 68, 219-226. [CrossRef]

49. Park, H.-K.; Shim, S.-S.; Kim, S.-Y.; Park, J.-H.; Park, S.-E.; Kim, H.-J.; Kang, B.-C.; Kim, C.-M. Molecular Analysis of Colonized Bacteria in a Human Newborn Infant Gut. J. Microbiol. Seoul Korea 2005, 43, 345-353.

50. Qin, J.; Li, R.; Raes, J.; Arumugam, M.; Burgdorf, K.S.; Manichanh, C.; Nielsen, T.; Pons, N.; Levenez, F.; Yamada, T.; et al. A Human Gut Microbial Gene Catalogue Established by Metagenomic Sequencing. Nature 2010, 464, 59-65. [CrossRef]

51. Tabasco, R.; Paarup, T.; Janer, C.; Peláez, C.; Requena, T. Selective Enumeration and Identification of Mixed Cultures of Streptococcus thermophilus, Lactobacillus delbrueckii subsp. bulgaricus, L. acidophilus, L. Paracasei subsp. paracasei and Bifidobacterium lactis in Fermented Milk. Int. Dairy J. 2007, 17, 1107-1114. [CrossRef]

52. García-Cayuela, T.; Tabasco, R.; Peláez, C.; Requena, T. Simultaneous Detection and Enumeration of Viable Lactic Acid Bacteria and Bifidobacteria in Fermented Milk by Using Propidium Monoazide and Real-Time PCR. Int. Dairy J. 2009, 19, 405-409. [CrossRef]

53. Botina, S.G.; Tsygankov, Y.D.; Sukhodolets, V.V. Phylogenetic Analysis of Type Strains of the Salivarius Group of the Genus Streptococcus Based on Their 16S RRNA Gene Sequences. Microbiology 2007, 76, 380-382. [CrossRef] 
54. Lick, S.; Teuber, M. Construction of a Species-Specific DNA Oligonucleotide Probe for Streptococcus thermophilus on the Basis of a Chromosomal LacZ Gene. Syst. Appl. Microbiol. 1992, 15, 456-459. [CrossRef]

55. Lick, S.; Keller, M.; Bockelmann, W.; Heller, J. Rapid Identification of Streptococcus thermophilus by Primer-Specific PCR Amplification Based on Its LacZ Gene. Syst. Appl. Microbiol. 1996, 19, 74-77. [CrossRef]

56. Tilsala-Timisjärvi, A.; Alatossava, T. Development of Oligonucleotide Primers from the 16S-23S RRNA Intergenic Sequences for Identifying Different Dairy and Probiotic Lactic Acid Bacteria by PCR. Int. J. Food Microbiol. 1997, 35, 49-56. [CrossRef]

57. Fujimoto, J.; Watanabe, K. Quantitative Detection of Viable Bifidobacterium Bifidum BF-1 Cells in Human Feces by Using Propidium Monoazide and Strain-Specific Primers. Appl. Environ. Microbiol. 2013, 79, 2182-2188. [CrossRef] [PubMed]

58. Ongol, M.P.; Tanaka, M.; Sone, T.; Asano, K. A Real-Time PCR Method Targeting a Gene Sequence Encoding 16S RRNA Processing Protein, RimM, for Detection and Enumeration of Streptococcus thermophilus in Dairy Products. Food Res. Int. 2009, 42, 893-898. [CrossRef]

59. Francavilla, R.; Ercolini, D.; Piccolo, M.; Vannini, L.; Siragusa, S.; De Filippis, F.; De Pasquale, I.; Di Cagno, R.; Di Toma, M.; Gozzi, G.; et al. Salivary Microbiota and Metabolome Associated with Celiac Disease. Appl. Environ. Microbiol. 2014, 80, 3416-3425. [CrossRef] [PubMed]

60. Pasolli, E.; Asnicar, F.; Manara, S.; Zolfo, M.; Karcher, N.; Armanini, F.; Beghini, F.; Manghi, P.; Tett, A.; Ghensi, P.; et al. Extensive Unexplored Human Microbiome Diversity Revealed by Over 150,000 Genomes from Metagenomes Spanning Age, Geography, and Lifestyle. Cell 2019, 176, 649-662. [CrossRef]

61. David, L.A.; Maurice, C.F.; Carmody, R.N.; Gootenberg, D.B.; Button, J.E.; Wolfe, B.E.; Ling, A.V.; Devlin, A.S.; Varma, Y.; Fischbach, M.A.; et al. Diet Rapidly and Reproducibly Alters the Human Gut Microbiome. Nature 2014, 505, 559-563. [CrossRef]

62. Taylor, B.C.; Lejzerowicz, F.; Poirel, M.; Shaffer, J.P.; Jiang, L.; Aksenov, A.; Litwin, N.; Humphrey, G.; Martino, C.; Miller-Montgomery, S.; et al. Consumption of Fermented Foods Is Associated with Systematic Differences in the Gut Microbiome and Metabolome. mSystems 2020, 5, e00901-19. [CrossRef]

63. Sanders, M.E.; Klaenhammer, T.R.; Ouwehand, A.C.; Pot, B.; Johansen, E.; Heimbach, J.T.; Marco, M.L.; Tennilä, J.; Ross, R.P.; Franz, C.; et al. Effects of Genetic, Processing, or Product Formulation Changes on Efficacy and Safety of Probiotics: On Efficacy and Safety of Probiotics. Ann. N. Y. Acad. Sci. 2014, 1309, 1-18. [CrossRef] [PubMed]

64. Kolaček, S.; Hojsak, I.; Berni Canani, R.; Guarino, A.; Indrio, F.; Orel, R.; Pot, B.; Shamir, R.; Szajewska, H.; Vandenplas, Y.; et al. Commercial Probiotic Products: A Call for Improved Quality Control. A Position Paper by the ESPGHAN Working Group for Probiotics and Prebiotics. J. Pediatr. Gastroenterol. Nutr. 2017, 65, 117-124. [CrossRef] [PubMed]

65. Mora, D.; Filardi, R.; Arioli, S.; Boeren, S.; Aalvink, S.; Vos, W.M. Development of Omics-based Protocols for the Microbiological Characterization of Multi-strain Formulations Marketed as Probiotics: The Case of VSL\#3. Microb. Biotechnol. 2019, 12, 1371-1386. [CrossRef] [PubMed]

66. Morovic, W.; Hibberd, A.A.; Zabel, B.; Barrangou, R.; Stahl, B. Genotyping by PCR and High-Throughput Sequencing of Commercial Probiotic Products Reveals Composition Biases. Front. Microbiol. 2016, 7, 1747. [CrossRef]

67. Lugli, G.A.; Mangifesta, M.; Mancabelli, L.; Milani, C.; Turroni, F.; Viappiani, A.; van Sinderen, D.; Ventura, M. Compositional Assessment of Bacterial Communities in Probiotic Supplements by Means of Metagenomic Techniques. Int. J. Food Microbiol. 2019, 294, 1-9. [CrossRef]

(C) 2020 by the authors. Licensee MDPI, Basel, Switzerland. This article is an open access article distributed under the terms and conditions of the Creative Commons Attribution (CC BY) license (http://creativecommons.org/licenses/by/4.0/). 